\title{
INDEPENDENT POLITICAL COMMITTEES AND THE FEDERAL ELECTION LAWS
}

In political election campaigns, persons or organizations can help finance a candidate in two basic ways. They can make their own expenditures for the candidate's benefit or they can make contributions to others-such as the candidate himself-who can spend the money on the candidate's behalf. ${ }^{1}$ In 1974, Congress amended the Federal Election Campaign Act (FECA) ${ }^{2}$ to limit such expenditures for a candidate ${ }^{3}$ and to reinstate limitations on contributions.4 The Supreme Court undertook a broad review of the FECA in the landmark decision of Buckley $v$. Valeo, 5 and there, for purposes of the first amendment, distinguished contributions from expenditures made independently of a candidate. ${ }^{6}$ The Court reasoned that although all spending of money in the political arena -where communication is so costly-is equivalent to speech, the direct expression by the person spending the funds deserves greater

I See 2 U.S.C. $\$ \$ 431(8)-(9)$ (Supp. III 1979), defining the terms "contribution" and "expenditure."

2 Federal Election Campaign Act Amendments of 1974, Pub. L. No. 93-443, 88 Stat. 1263 (1974) [hereinafter cited as FECA 1974] (amending Federal Election Campaign Act of 1971, Pub. L. No. 92-225, 86 Stat. 3 (1972) [hereinafter cited as FECA 1971] and Revenue Act of 1971, Pub. L. No. 92-178, titles 7-8, 85 Stat. 560 (1971) [hereinafter cited as Revenue Act]).

3 FECA 1974, Pub. L. No. 93-443, \$101(e)(1), 88 Stat. 1263 (1974) (repealed, Pub. L. No. 94-283, 90 Stat. 475 (1976)). The section had provided that "[n]o person may make any expenditure .... relative to a clearly identified candidate during a calendar year which, when added to all other expenditures made by such person during the year advocating the election or defeat of such candidate, exceeds \$1,000." Id. The statute has always defined "person" as "an individual, partnership, committee, association, corporation, labor organization, and any other organization or group of persons ...." FECA 1971, Pub. L. No. 92-225, \$301(h), 86 Stat. 3 (1972) (currently found at 2 U.S.C. $\$ 431$ (11) (Supp. III 1979)).

4 The Hatch Act of 1939, entitled "An Act to prevent pernicious political activities," Pub. L. No. 76-252, 53 Stat. 1147 (1939), as amended by Pub. L. No. 76-743, 54 Stat. 767 (1940), established contribution limitations of $\$ 5,000$ per calendar year to any candidate for federal office. Pub. L. No. 76-743, \$13(a), 54 Stat. 767 (1940) (codified before repeal at 18 U.S.C. $\$ 608$ ) (repealed, Pub. L. No. 94-283, $\$ 201$ (a), 90 Stat. 475 (1976)). It remained essentially intact until 1971, when its provisions on contribution limitations were dropped by FECA 1971. Pub. L. No. 92-225, \$203, 86 Stat. 3 (1972). In 1974, however, contribution restrictions were reinstated by amendments to the FECA: individual contributions to a candidate in a calendar year were limited to $\$ 1,000$. FECA 1974, Pub. L. No. 93-443, $\$ 101(\mathrm{~b}), 88$ Stat. 1263 (1974). The restriction thus matched the newly added expenditure limitation. See note 3 supra.

5424 U.S. 1 (1976).

6 Id. 19-21. 
protection than does the contribution of money to others to spend on a campaign.7 Consequently, the Court held unconstitutional the FECA's limitations on independent campaign expenditures, ${ }^{8}$ while it upheld the limitations on contributions. ${ }^{9}$

The Court's holding significantly altered the functioning of the regulatory scheme established by the federal election laws. In the early 1970s, on the tide of a rising demand for election reform, Congress took successive steps to prevent corruption in presidential election campaigns by revising the federal election laws. ${ }^{10}$ Starting with bills that placed limits on campaign contributions, but not on expenditures made for the benefit of a candidate, legislators foresaw that a failure to restrict expenditures would enable individuals and groups who had reached their limits on contributions to simply run their own parallel campaigns for the candidates they support. ${ }^{11}$ Congress therefore, in passing the 1974 FECA amendments, limited the expenditures that could be made on behalf of a candidate. ${ }^{12}$ Buckley struck down that provision, however, thereby opening an "expenditure loophole" in the FECA.

Within fifty days after the decision was announced, ${ }^{13}$ Congress amended the election laws to correct the constitutional errors

${ }^{7}$ Id. For general discussions of the Court's decision, see Polsby, Buckley v. Valeo: The Special Nature of Political Speech, 1976 Sup. Cr. Rev. 1 (1976); Wright, Politics and the Constitution: Is Money Speech?, 85 YALE L.J. 1001 (1976).

8424 U.S. at 51.

9 Id. 29.

10 Beginning in 1971, Congress provided for the establishment of public funding for presidential general election campaigns (the scheme would not be fully effective until after the 1972 election), and for tax incentives to encourage small contributions to candidates. Revenue Act, Pub. L. No. 92-178, $\$ \$ 701-703,9001-9013,85$ Stat. 560 (1971). In 1972, Congress enacted broad reporting and disclosure requirements pertaining to all campaign financing. FECA 1971, Pub. L. No. 92-225, $\$ \$ 301-311,86$ Stat. 3 (1972). In 1974, further changes were made to complete the scheme. Among these were the extension of the public financing concept to presidential primary elections, reinstatement of contribution limitations, and the addition of restrictions on independent expenditures. FECA 1974, Pub. L. No. 93-443, $\$ \$ 101-103,408,88$ Stat. 1263 (1974).

11 The Senate Rules and Administration Committee, in its report on the FECA Amendments of 1974, stated:

Whether campaigns are funded privately or publicly such controls [on independent expenditures] are imperative if Congress is to enact meaningful limits on direct contributions. Otherwise, wealthy individuals limited to a $\$ 3,000$ direct contribution could also purchase one hundred thousand dollars' worth of advertisements for a favored candidate. Such a loophole would render direct contribution limits virtually meaningless.

S. REP. No. 689, 93d Cong., 2d Sess. 18 (1974), reprinted in [1974] U.S. Code Conc. \& AD. NEws 5587, 5604.

12 See note 3 supra.

13 The Supreme Court, having invalidated certain features of the Federal Election Commission's constitution, granted a stay of its decision with regard to the 
found by the Court. ${ }^{14}$ Despite congressional attempts to narrow as much as possible the newly created right to make independent expenditures, ${ }^{15}$ problems soon arose. This Comment examines, in the context of presidential general election campaigns, ${ }^{16}$ the issues arising from this revised treatment of independent expenditures.

The major objections to the expenditure loophole in the presidential general election context stem from the fact that political committees purporting to be independent may raise and spend large sums of money in support of a candidate, thereby running a cam-

authority of the Commission for a period of 30 days. 424 U.S. at 144. The stay was later extended an additional 20 days. S. ReP. No. 677, 94th Cong., $2 \mathrm{~d}$ Sess. 61 (1976).

14 Federal Election Campaign Act Amendments of 1976, Pub. L. No. 94-283, 90 Stat. 475 (1976) [hereinafter cited as FECA 1976], as amended by Federal Election Campaign Amendments of 1979, Pub. L. No. 96-187, 93 Stat. 1339 (1980).

15 The House Committee on House Administration, in its report on the proposed 1976 FECA amendments, included among the purposes of the bill the following:

[P]rior to 1971 the laws regulating Federal campaigns permitted an infinite proliferation of political committees which were ostensibly separate entities but which were in fact a means for advancing a candidate's campaign. That deficiency brought the campaign laws into disrepute and provided an essential predicate for the 1971 and 1974 reforms that the Congress enacted. Buckley v. Valeo's invalidation of the limitations placed by the 1971 Act, as amended, on individual expenditures and on candidate expenditures promises a repetition of the pre-1971 experience. To prevent that result, while safeguarding the full enjoyment of the First Amendment right of individuals and groups to make expenditures for political expression, H.R. 12406 contains a series of prophylactic measures. These are directed solely at requiring full reporting and disclosure by individuals and groups that make "independent expenditures" ( $a$ term defined in the bill in conformity with the Buckley Court's definition); and at placing several additional limitations akin to those upheld by the Court on the amount that may be contributed by or to a political committee.

H.R. ReP. No. 917, 94th Cong., 2d Sess. 5 (1976), reprinted in Federal Election Commisston, Legrislative History of Federal Election Campaign Act AMandMENTS of 1976, at 797, 805 (1977).

FECA 1976 narrowly defined an "independent expenditure" as an

expenditure by a person expressly advocating the election or defeat of a clearly identified candidate which is made without cooperation or consultation with any candidate, or any authorized committee or agent of such candidate, and which is not made in concert with, or at the request or suggestion of, any candidate or any authorized committee or agent of such candidate.

FECA 1976, Pub. L. No. 94-283, $\$ 102(\mathrm{~g}), 90$ Stat. 475 (1976) (currently found at 2 U.S.C. $\$ 431$ (17) (Supp. III 1980)).

16 Although this Comment, like the cases with which it deals, primarily addresses the activities of independent committees during the presidential general election, similar provisions also apply to candidates who accept public funding in the primaries. See I.R.C. $\$ 9031-9042$. The election laws relating to campaigns for congressional seats also will not be discussed here, except as such references may be relevant to the more general issues raised by the expenditures of independent, multicandidate political committees. 
paign parallel to that of the candidate's authorized campaign. Assuming the candidate has accepted public financing, ${ }^{17}$ his official committees are expressly disallowed from accepting private contributions, and are expressly limited in the amount they can spend; the unofficial and unconnected committee working for the candidate's election knows no such limits. At least three congressional objectives in passing the public financing and regulatory system are potentially impaired by the operation of parallel campaigns: the prevention of corruption or its appearance, ${ }^{18}$ the institution of some form of rough parity in spending for major candidates, ${ }^{19}$ and the protection of the overall regulatory scheme. ${ }^{20}$

In 1976, the first presidential election in which the public funding scheme applied, the level of activity by independent political committees was relatively insignificant. ${ }^{21}$ This resulted at least partly from uncertainty about the new rules.22 By June 1980, however, at least five separate independent ${ }^{23}$ groups were organized, with plans to spend collectively from $\$ 38$ million to $\$ 58$ million in support of Ronald Reagan, the likely Republican presidential nominee at that time. ${ }^{24}$ Because the Presidential Election Campaign Fund Act (Fund Act) would limit each major party candidate to receiving $\$ 29.4$ million from the Treasury for their campaigns, ${ }^{25}$ the projected spending by these independent committees appeared

17 For an overview of the public financing system and related regulations, see notes 66-98 infra \& accompanying text.

18 See note 118 infra \& accompanying text.

19 See notes 123 \& 223 infra \& accompanying text.

20 See notes 121 \& 122 infra \& accompanying text.

21 The reported independent expenditures on behalf of Gerald Ford's candidacy were only $\$ 216,715$; expenditures on behalf of Jimmy Carter totalled an even less significant $\$ 74,298$. H. Alexander, Financing the 1976 ELECTION 408, 363 (1979).

22 Id. $363-65,407-10$.

23 Although this Comment will attempt to raise questions concerning the true independence of these groups, it will refer to them throughout as "independent political committees" because that is how they are popularly known.

24 N.Y. Times, July 2, 1980, at A17, col. 5.

25 I.R.C. $\$ \$ 9003(b)(I), 9004(a)(1)$. These sections refer to the FECA for determining the actual contribution limits. That Act provides for $\$ 20$ million in public financing for major-party candidates, as adjusted with inflation. 2 U.S.C. $\$ \$ 441 \mathrm{a}(\mathrm{b})(\mathrm{I})(\mathrm{B}), 44 \mathrm{la}$ (c) (1976). The Act also provides that each party's national committee can spend an additional amount over and above this year's $\$ 29.4$ million figure, determined as a function of the voting age population. 2 U.S.C. $\$ 441$ (d) (1976). In 1980, that amount was $\$ 4.7$ million. N.Y. Times, June 23, 1980 , at $\mathrm{A} 21$, col. 3 . 
capable of creating a significant disparity in spending between the campaigns of nominees Reagan and Carter. ${ }^{20}$

Several legal actions were instituted in response to these circumstances. In Common Cause $v$. Schmitt, ${ }^{27}$ the plaintiff public interest group initially filed suit against one of the independent committees, Americans For Change, and later added two other committees as defendants. ${ }^{28}$ In its two-count complaint, Common Cause charged, first, that it was unlawful under the statute for the committees to spend more than $\$ 1000$ on Reagan's behalf, regardless of whether they were truly independent of Reagan's official campaign organization; alternatively, it charged that the committees could not spend more than that amount because, as a factual matter, they were not independent. ${ }^{29}$ The Federal Election Commission (FEC or Commission) brought a separate action against Americans For Change, making the same charge as in the first count of the Common Cause complaint; the actions were subsequently consolidated. $^{30}$ Both plaintiffs sought declaratory and injunctive relief against the defendant committees. Both suits were unsuccessful, but have been appealed to the Supreme Court, which has noted probable jurisdiction. ${ }^{31}$ In a related action, the Carter-Mondale Reelection Committee (Carter-Mondale) filed a complaint on July 2, 1980 with the FEC, requesting, inter alia, that the Commission decline to certify Reagan for public funding in the general election on the ground that because of the activities of the "allegedly independent committees," the Fund Act and the FECA would be violated if Reagan should seek and receive public funding. ${ }^{32}$ Two

${ }^{26}$ N.Y. Times, June 23, 1980, at A21, col. 3.

Another source of potentially serious spending imbalances, the corporate or labor political action committee, is considered at notes 194-205 infra \& accompanying text.

27 No. 80-1609 (D.D.C. Sept. 30, 1980), prob. juris. noted, 49 U.S.L.W. 3616 (U.S. Feb. 24, 1981) (No. 80-847).

28 Plaintiff's Opening Brief on the Merits at 8, Common Cause v. Schmitt, No. 80-1609 (D.D.C. Sept. 30, 1980), prob. juris. noted, 49 U.S.L.W. 3616 (U.S. Feb. 24,1981 ) (No. 80-847).

$29 \mathrm{Id} .24,50$.

30 FEC v. Americans for Change, No. 80-1754 (D.D.C. Sept. 30, 1980), prob. juris. noted, 49 U.S.L.W. 3616 (U.S. Feb. 24, 1981) (No. 80-1067), consolidated for decision with Common Cause v. Schmitt. The FEC intervened as a defendant in the Common Cause suit, arguing that the plaintiff's complaint there should be dismissed for lack of subject-matter jurisdiction.

3149 U.S.L.W. 3616 (U.S. Feb. 24, 1981).

32 Complaint at 2, Carter-Mondale Reelection Comm., Inc. v. Reagan (certification granted by the FEC July 24, 1980), aff'd, No. $80-1842$ (D.C. Cir. Sept. 12, 1980). Alternatively, the complaint requested that the Commission commence an investigation into possible violations of the election laws by the committees. Id. 39. 
weeks later, Ronald Reagan officially received the Republican nomination for President, and after filing the requisite papers, was certified to receive payments under the Fund Act. Immediately thereafter, Carter-Mondale filed an appeal in the U.S. Court of Appeals for the District of Columbia Circuit, seeking reversal of the FEC certification decision. The appeal was not successful..$^{33}$

Although the feared huge disparity in funding did not materialize, ${ }^{34}$ the questions posed by these cases remain relevant today. How can or should Congress and the courts regulate purportedly independent political committees in a way that preserves the integrity of the federal election laws without violating the constitutional rights of these groups and their members? Can the funds collected and expended by these groups be directly limited, regardless of whether the groups are independent? What can private litigants do to challenge and control expenditures by non-independent committees? Part I of this Comment provides some factual background on the nature of the independent political committees that supported then-candidate Reagan in the 1980 election. Part II discusses the recent cases in terms of the possible strategies they suggest for controlling the committees. This part concludes, first, that because of Buckley the district court in Common Cause properly held unconstitutional a statutory restriction on expenditures by political committees. Second, it concludes that the only action available during a campaign to challenge "independent" expenditures, filing a complaint with the FEC, is an empty remedy because the Commission's investigation almost certainly will continue beyond election day, and the sanctions available to the Commission or courts at that time will be inadequate to properly redress a violation of the Act. Part III suggests that the impact that these committees have on presidential elections may be reduced by permitting contributions directly to the candidate during the general election, and by raising the limitation on individual contributions to candidates. ${ }^{35}$

33 Carter-Mondale Reelection Comm., Inc. v. FEC, No. 80-1842 (D.C. Cir. Sept. 12, 1980).

34 See notes $43-45$ and $48-50$ infra \& accompanying text.

35 This Comment will focus on the independent committees that supported President Reagan rather than those that supported President Carter because of the enormous disparity in their respective levels of expenditures, and, consequently, the disparity in the amount of information (from the media) available on the two groups of committees. The former group outspent the latter group by about 100 to 1 : according to the New York Times, pro-Reagan committees spent $\$ 10$ million as opposed to expenditures by pro-Carter committees of $\$ 0.1$ million. Smith, Financing Campaign '80: Would You Believe Half a Billion?, N.Y. Times, Nov. 23, 1980, at E3, col. 1. 


\section{Factual Background: The INDEPENDENT Political Committees}

The plaintiff's brief in Common Cause v. Schmitt ${ }^{36}$ described the independent committees as "centrally managed organizations that solicit contributions broadly but place control over how the money will be spent in the hands of a few persons-generally political professionals." 37 The 1980 committees "operate[d] large, professionally run', purportedly 'independent' partisan campaigns on behalf of" Reagan and other Republican candidates for federal office. ${ }^{38}$ The brief's description seems reasonably accurate. ${ }^{39}$

As of July 1980, there were at least five committees, listed below, planning to support Reagan with independent expenditures.40 Collectively, these groups estimated that they would spend at least $\$ 38$ million on the campaign. ${ }^{41}$ The largest of these groups in terms of spending expectations was Americans for Change (AFC), which announced a goal of raising and spending $\$ 20-\$ 30$ million. ${ }^{42}$ The money would be spent on a combination of television, radio, and newspaper ads, and direct mailings to voters.

The independent groups' actual spending, however, fell far below their expectations. By October 31, 1980, five days before the election, the FEC's preliminary figures showed expenditures on the presidential election by all independent committees to be $\$ 10.7$ million..$^{43}$ As of October 31, 1980, the leading spenders in all races were as follows:

36 Plaintiff's Opening Brief on the Merits, Common Cause v. Schmitt, No. 80 1609 (D.D.C. Sept. 30, 1980), prob. juris. noted, 49 U.S.L.W. 3616 (U.S. Feb. 24, 1981) (No. 80-847).

37 Id. 47.

38 Id. 7. Apparently, no comparable committee action took place to help Carter. See Wall St. J., June 19, 1980, at 1, col. 1.

39 See notes 40-59 infra \& accompanying text.

40 N.Y. Times, July 2, 1980, at A17, col. 5. By the middle of the month there were at least seven groups. N.Y. Times, July 15, 1980, at B9, col. 2.

41 N.Y. Times, July 2, 1980, at Al7, col. 5.

42 Wall St. J., June 19, 1980, at 1, col. 1. By the middle of September, however, after the Common Cause litigation had taken place, AFC's fundraising expectations had been lowered significantly. Claiming that "the Court battle has interfered with our efforts and obviously has had a chilling effect on our fundraising activities . . ." AFC reported in September that it had raised $\$ 300,000$. Its revised plan was to raise a total of $\$ 3-\$ 5$ million, to be spent primarily on a "voter kit program" and newspaper and electronic media advertising. AFC Progress Report (Sept. 5, 1980) (on file with the University of Pennsylvania Law Review); telephone interview with Maria Dennison, AFC Press Secretary (Sept. 10, 1980).

43 Press Release, Federal Election Commission (Oct. 31, 1980) (on file with the University of Pennsylvania Law Review). 
National Conservative Political Action Committee

Congressional Club

Fund for a Conservative Majority

Americans for an Effective Presidency

Americans for Change

$\$ 4$ million

$\$ 3$ million

$\$ 2$ million

$\$ 0.8$ million

$\$ 0.5$ million 44

Much of the shortfall was blamed on the Common Cause, FEC, and Carter-Mondale litigation..$^{45}$ Although the negative publicity generated by this litigation probably did have a chilling effect on fundraising, much of the shortfall is probably equally attributable to the unrealistic expectations of the committees, especially the newer ones.

The committees raised their money primarily through direct mail solicitations of individuals, who may contribute up to $\$ 5000$ to any political committee, ${ }^{46}$ and through the sponsorship of various fundraising events. The groups traded directly upon the inability of the candidates to receive contributions once they accepted federal funding. Consider, for example, an excerpt from one of the AFC brochures: "Federal Law Prohibits Ronald Reagan from accepting your personal contribution. But ...." The brochure proceeded to explain how the reader could legally support Ronald Reagan's candidacy by contributing to the AFG committee. ${ }^{47}$

As a result of the importance of the direct mail solicitations, the control of mailing lists became crucial. The New York Times reported that Reagan's primary campaign relied heavily on funds collected through mail solicitations of small contributors:

The fountainhead of Mr. Reagan's mail drive was a list of 180,000 names left over from his unsuccessful 1976 Presidential campaign. The list became the property of Citizens for the Republic ["CFTR"], an organization started by Mr. Reagan and his aides as a fund-raising vehicle for conservative causes. The Citizens for the Re-

44 Id.

45 See, e.g., AFC Progress Report, supra note 42. See also Ifshin \& Warin, Litigating the 1980 Presidential Election, at 35 (1980) (unpublished article on file with the University of Pennsylvania Law Review).

462 U.S.C. $\$ 441 \mathrm{a}(\mathrm{a})(\mathrm{I})(\mathrm{C})$ (1976). By contrast, an individual may not contribute more than $\$ 1,000$ directly to any candidate and his or her authorized committees with respect to any election for federal office, 2 U.S.C. $\$ 441 a(a)(1)(A)$ (1976), with the exception of course that one may not contribute anything in the general election to a major-party presidential candidate who has accepted public funding. I.R.C. $\$ 9003(\mathrm{~b})$. An individual is allowed to contribute up to $\$ 25,000$ in a calendar year. 2 U.S.C. $\$ 441 a(a)(3)$ (1976).

47 Campaign literature of Americans for Change (on file with the University of Pennsylvania Law Review). 
public's list, in turn, has been rented in a growing mailing-list market to a wide array of conservative groups, including the Fund for a Conservative Majority. ${ }^{48}$

Other private organizations controlling their own conservative mailing lists also made their lists available to several of the independent committees.99 By becoming increasingly reliant on the same mailing lists, however, it is possible that the committees approached the saturation point on individual contributions-at least, that might help to explain why the newer committees that did not have their own lists did not raise more funds than they did. .0

Each of the five committees filed with the FEC as multicandidate committees, and none filed as "authorized" committees of the Reagan campaign. Three of the committees-Fund for a Conservative Majority, North Carolina Congressional Glub, and National Conservative Political Action Committee-had been organized in the early 1970s, thus substantially pre-dating the 1980 Reagan campaign. Several of the groups formed projects with such names as "Reagan for President in '80," "Citizens for Reagan in '80," and "Americans for Reagan." ${ }^{51}$ They could not file their committees under such titles because the FECA prevents them from so using the candidate's name. ${ }^{\mathbf{2}}$

Most of the committees explicitly told their contributors that an executive committee within the group would make all decisions on expenditures. ${ }^{53}$ The executive committees were all controlled by political professionals-people with longstanding ties to the Republican Party or to the candidate himself. Americans For Change, for example, was headed by Republican Senators Harrison $\mathrm{H}$. Schmitt of New Mexico and David Durenberger of Minnesota; John Harmer, the former Lieutenant Governor of California under then-Governor Reagan, and Carl T. Curtis, a former Republican

48 N.Y. Times, June 30,1980 , at B13, col. 1.

49 July 15, 1980, Supplement to Complaint at 4, Carter-Mondale Reelection Comm., Inc. v. Reagan (certification granted by the FEC July 2A, 1980), aff'd, No. 80-1842 (D.C. Cir. Sept. 12, 1980).

50 Telephone interview with Professor Herbert Alexander (Jan. 6, 1981).

51 Plaintiff Federal Election Commission's Local Rule 1-9(h) Statement of Material Facts As to Which There is No Genuine Dispute [hereinafter cited as FEC's Statement of Material Facts], FEC v. Americans For Change, No. 80-1754 (D.D.C. Sept. 30, 1980), prob. juris. noted, 49 U.S.L.W. 3616 (U.S. Feb. 24, 1981) (No. 80-1067).

ธ2 2 U.S.C. $\$ 432$ (e)(4) (Supp. III 1979).

63 See, e.g., campaign literature of Americans for Change (on file with the University of Pennsylvania Law Review). 
Senator from Nebraska. ${ }^{54}$ Republican Senator Jesse Helms of North Carolina was the Honorary Chairman of Americans For Reagan, a project of the North Carolina Congressional Club (NCCC). The organizers of Americans for an Effective Presidency (AEP), a group planning to spend $\$ 12-15$ million (but eventually spending only $\$ .8$ million), included Thomas Reed, co-chairman of Reagan's 1970 campaign for Governor of California; Peter Flanigan, a member of the Advisory Council on Economic Affairs of the Republican National Committee; James Lake, the coordinator of Reagan's primary campaign in New Hampshire in 1976, and Stuart Spencer, who ran Reagan's campaigns for Governor of California in 1966 and 1970 and who subsequently would leave AEP to join Reagan's official campaign staff. ${ }^{55}$

Although by law independent committees are prevented from coordinating their activities with the candidate or his authorized agents, the independent committees did not seem to have a problem in planning appropriate strategies for using their funds. Because of the wealth of information reported in the media and the use of political consultants, the committees may have no need to coordinate directly their activities. Kenneth Boehm, treasurer of the Fund for a Conservative Majority, stated during the campaign that members of his group scrupulously avoided contact with Reagan campaign aides "to the point that we we avoid them at cocktail parties." Nevertheless, he added that "we pretty much know what the Reagan campaign strategy is from the newspapers." 58 Fred Wertheimer, Common Cause vice president, commented that " $t]$ he law says Stu Spencer can't talk to anybody in the Reagan campaign. But of course he doesn't have to; he knows what needs to be done and how to get it done." 57 For the most part, the committees' leaders made efforts to avoid contact with Reagan campaign offcials. ${ }^{68}$ One exception was brought to light by a remark that Senator Jesse Helms made to Sander Vanocour of ABC News at the time of the Republican National Convention. Asked whether he had discussed with Governor Reagan the selection of a vice presidential nominee, the Senator replied:

54 Campaign literature of Americans for Change (on file with the University of Pennsylvania Law Review).

55 See Complaint at 18-21, Carter-Mondale Reelection Comm., Inc. v. Reagan (certification granted by the FEC July 24, 1980), aff'd, No. 80-1842 (D.C. Cir. Sept. 12, 1980); Wash. Star, July 11, 1980, at A-4.

56 N.Y. Times, June 30,1980 , at B13, col. 1 .

57 Wall St. J., June 19, 1980, at 20, col. 1.

58 N.Y. Times, June 23, 1980, at A21, col. 3; N.Y. Times, June 30, 1980, at B13, col. 1 . 
Well, as you may know, we have had an independent effort on in North Carolina. The law forbids me to consult with him and it's been an awkward situation. I've had to, sort of, talk indirectly with Paul Laxalt [Reagan's campaign manager and Senator from Nevada] and hope that he would pass along, uh, and I think the messages have gotten through all right. ${ }^{59}$

Although the remark is not without ambiguity, it at least suggests an attempt to circumvent the prohibition on consultation with the candidate or his agents.

\section{The Litigated Statutory Challenges to the INDEPENDENT COMMITTEES}

During the course of the 1980 campaign, the Common Cause v. Schmitt ${ }^{60}$ and FEC $v$. Americans for Change ${ }^{61}$ suits were filed seeking to halt, through declaratory and injunctive relief, the efforts of the independent committees. With a different remedy in mind, the Carter-Mondale Reelection Committee, Inc. v. Reagan ${ }^{62}$ complaint was brought before the FEC to have the committees' expenditures treated as private funding that had been accepted by Reagan, thereby precluding Reagan from receiving public funding. Although Carter-Mondale was motivated primarily by partisanship, ${ }^{83}$ Common Cause's opposition stemmed from its belief that, as stated by its chairman, Archibald Cox, the independent efforts would "subvert the scheme enacted by Congress for the federal funding of Presidential elections." 44 Before assessing the merits of the claims

69 July 23, 1980, Supplement to Complaint at 1, Carter-Mondale Reelection Comm., Inc. v. Reagan (certification granted by the FEC July 24, 1980), aff'd, No. 80-1842 (D.C. Cir. Sept. 12, 1980).

60 No. $80-1609$ (D.D.C. Sept. 30, 1980), prob. juris. noted, 49 U.S.L.W. 3616 (U.S. Feb. 24, 1981) (No. 80-847).

61 No. 80-1754 (D.D.C. Sept. 30, 1980), prob. juris. noted, 49 U.S.L.W. 3616 (U.S. Feb. 24, 1981) (No. 80-1067).

62 Certification granted by the FEC July 24, 1980, aff'd, No. 80-1842 (D.C. Cir. Sept. 12, 1980).

63 The lawusit is fast becoming an important weapon in the campaign manager's arsenal. See Ifshin \& Warin, supra note 45 , at 58 .

64 N.Y. Times, July 2, 1980, at A17, col. 5.

Common Cause has a history of involvement in the enforcement and legislation of federal election laws, dating back at least to 1971, when it brought suit against the Democratic National Committee to seek enforcement of the Federal Corrupt Practices Act. See Common Cause v. Democratic Nat'l Comm., 333 F. Supp. 803 (D.D.C. 1971). Common Cause was also one of the most significant forces behind the FECA Amendments of 1974. See Fleishman \& Greenwald, Public Interest Litigation and Political Finance Reform, 425 AnNars 114 (May 1976). 
presented in these cases, it will be helpful to provide at this point a brief overview of some of the major provisions of the election statutes. ${ }^{\text {es }}$

\section{A. The Federal Election Laws}

The federal election laws, including the Federal Election Campaign Act and Subtitle $\mathrm{H}$ of the Revenue Act of 1971 (collectively referred to as the Act or the FECA), ${ }^{66}$ provide a comprehensive system for regulating the elections to all federal offices and for publicly financing presidential elections. The scheme features contribution limitations and disclosure requirements; a matching grant system for candidates in primary presidential elections and full, conditional funding of general presidential elections, and provisions for administration and enforcement by an independent Federal Election Commission.

\section{Contribution Limitations}

The Act places a limit of $\$ 1,000$ on contributions by any person to a candidate or his authorized committees in any calendar year. ${ }^{67}$ It places a limit of $\$ 5,000$ on contributions by persons to other political committees in the same period. ${ }^{68}$ Multicandidate political committees may make contributions of up to $\$ 5,000$ to a candidate or his authorized committees, or to other political committees. $^{69}$ Each of these contribution limitations applies separately with respect to each election held in a calendar year, with the exception that all presidential primaries are considered to be one election. ${ }^{70}$ There is no limit on the aggregate amount a multicandidate committee can contribute in a given year: such a committee can give up to $\$ 5,000$ to an unlimited number of candidates for various offices. Within a calendar year, however, an individual may not make contributions aggregating more than $\$ 25,000.71$ Ad-

65 For a discussion of the development of the federal election laws between FECA 1971, FECA 1974, and FECA 1976, see Note, Current Status of the Federal Election Campaign Act: Buckley v. Valeo and the Legislative Response, 45 U. CrN. L. Rev. 623 (1976).

66 See notes 2 \& 14 supra.

672 U.S.C. $\$ 441 \mathrm{a}(\mathrm{a})(1)(\mathrm{A})(1976)$.

68 Id. $\$ 441 \mathrm{a}(\mathrm{a})(1)(\mathrm{C})$.

$69 \mathrm{Id}$. $\$ 441 \mathrm{a}(\mathrm{a})(2)$.

$20 \mathrm{Id}$. $4 \mathrm{la}(\mathrm{a})(6)$.

7I Id. $\$ 441 a(\mathrm{a})(3)$. 
ditional limitations apply to contributions by banks, corporations and labor unions. ${ }^{72}$

\section{Reporting and Disclosure Requirements}

The Act sets forth a number of registration and record-keeping requirements for all political committees. For the purposes of the reporting and disclosure requirements, a political committee is defined as "any committee, club, association or other group of persons which receives contributions ... or which makes expenditures aggregating in excess of $\$ 1,000$ during a calendar year." 73 A political committee must file a statement-of-organization form with the FEC within ten days after its organization, or after it anticipates raising or spending $\$ 1,000 .^{74}$ Committee treasurers are responsible for keeping records of all contributions received and expenditures made by the committee. ${ }^{75}$ Each contribution of more than fifty dollars must be identified by the name and address of the donor, the date it was received, and the amount. ${ }^{78}$ All transfers of funds by the committee must be identified, regardless of amount, by the date, amount, recipient, and name and address of each candidate on whose behalf the expenditure was made. ${ }^{77}$

Each registered committee is required to file periodic reports with the FEC until the committee has terminated its operations. ${ }^{78}$ The reports must disclose the amount of cash on hand; the total amount of receipts for the reporting period and the calendar year, including contributions, transfers, loans, refunds, and dividends; the name of each political committee that made a contribution or transfer to the reporting committee, and the name of each person whose aggregate contributions exceeded $\$ 200$ during the calendar year. Similar disclosures must be made regarding all expenditures by the reporting committee. ${ }^{79}$ In addition, every person (other than a

72 Id. $\$ 441 \mathrm{~b}$. These provisions are considered in more detail at notes 194-203 infre \& accompanying text.

732 U.S.C. $\$ 431(4)(A)$ (Supp. III 1979). The Fund Act defines political committees more broadly: "any committee, association, or organization . . . which accepts contributions or makes expenditures for the purpose of influencing or attempting to influence, the nomination or election of one or more individuals to Federal, State, or local elective public office." I.R.C. $\$ 9002(\theta)$.

742 U.S.C. $\$ 433$ (a) (Supp. III 1979).

75 Id. $\$ 432(\mathrm{c})$.

${ }^{76}$ Id. $\$ 432(c)(2)$.

7r Id. $\$ 432(c)(5)$.

78 Id. $\$ 434$ (a):

79 Id. $\$ 434$ (b). 
political committee) who makes independent expenditures aggregating over $\$ 250$ in a calendar year must file an individual statement. ${ }^{80}$

\section{Public Funding of Presidential Election Campaigns}

Subtitle $\mathrm{H}$ of the Revenue Act of $1971^{81}$ provides for the public subsidization of presidential primary and general elections. The Act establishes within the United States Treasury a "Presidential Election Campaign Fund" 82 that is financed by a tax checkoff system. An individual may designate that one dollar of his tax payment be used in the fund. ${ }^{83}$ The fund is the source of all public payments to eligible presidential candidates. In the primaries, a grant system allocates to each eligible candidate up to five million dollars (inflation-adjusted) in payments that match the contributions that the candidate has received not exceeding $\$ 250$ per person. ${ }^{84}$ In order to be eligible, a candidate must seek a party nomination, agree to observe the Act's spending limits, and collect more than $\$ 5,000$ in contributions not exceeding $\$ 250$ individually from residents of each of at least twenty states. ${ }^{85}$ For the general election, full subsidization-twenty million in 1974 dollars, as adjusted for inflation as measured by the Consumer Price Index-is provided for major party candidates who opt for public funding; ${ }^{86}$ minor and new party candidates are given separate entitlements. ${ }^{87}$

A candidate must agree to several conditions in order to qualify for public funding. First, he must agree not to make expenditures in excess of $\$ 50,000$ from personal or family funds. ${ }^{88}$ In the primaries, an eligible candidate must agree to limit expenditures to $\$ 10$ million; ${ }^{89}$ in the general election campaign, expenditures are limited to the amount provided by public funding.90 In addition, candidates accepting public funding must agree to be audited and examined by the Commission. ${ }^{91}$

80 Id. $\$ 434$ (c)(I).

81 I.R.C. $\$ \$ 9001-9042$.

82 Id. $\$ 9006$ (a).

83 Id. $\$ 6096(a)$. Married taxpayers who file jointly may designate that two dollars be paid to the fund.

84 Id. $\$ 9034 ; 2$ U.S.C. $\$ 441 \mathrm{la}(\mathrm{b})-(\mathrm{c})$ (1976).

85 I.R.C. $\$ 9033(b)$.

$86 I d . \$ 9004(a)(1) ; 2$ U.S.C. $\$ 441 \mathrm{a}(\mathrm{b})-(\mathrm{c})$ (1976).

87 I.R.C. $\$ \$ 9004(a)(2)-(3), 9004$ (d).

$88 I d . \S 9004(\mathrm{~d})$.

89 Id. $\$ 9035(\mathrm{a}) ; 2$ U.S.C. $\$ 441 \mathrm{a}(\mathrm{b})$ (1976).

90 I.R.C. $\$ \$ 9003(\mathrm{~b})$ (1), 9004(a)(1). See 2 U.S.C. $\$ 441 \mathrm{la}(\mathrm{b})$ (1976).

91 I.R.C. $\$ \S 9003(a)(3), 9033(a)(3)$. 


\section{Coordinated Expenditures}

The benefit to a candidate of the independent expenditure "loophole" is that independent expenditures in support of his candidacy do not count against its contribution or expenditure limits, and those independent expenditures are unlimited. The cost to a candidate of having a supportive, non-authorized committee classified by the FEC as not truly independent is that all expenditures by that committee will be treated as contributions in kind to and expenditures by the candidate and his authorized committee. ${ }^{92}$ This may place a given candidate and his authorized committee above their legal expenditure limit, thereby exposing them to possible criminal penalties for exceeding the limit ${ }^{93}$ and for filing false statements with the FEC. ${ }^{94}$

\section{The Federal Election Commission}

The FECA is administered by an independent Federal Election Commission. The Commission, composed of eight members, ${ }^{95}$ a general counsel, and additional staff, ${ }^{96}$ has exclusive jurisdiction over the civil enforcement of the Act. ${ }^{97}$ It has power to conduct investigations and hearings, render advisory opinions, initiate civil actions for injunctive, declaratory, or other relief, and make regulations pursuant to the Act.98 Criminal prosecutions are handled by the Justice Department. ${ }^{98}$

\section{B. Section 9012(f) of the Fund Act}

\section{Plaintiffs' Arguments}

In both Common Cause and Americans For Change, the plaintiffs argued that section 9012(f) of the Fund Act, ${ }^{100}$ which had not been discussed in Buckley $v$. Valeo, ${ }^{101}$ prevented the defendant com-

9211 C.F.R. $\$ 109.1$ (c) (1980). Buckley v. Valeo, 424 U.S. 1, $46-47$ (1976), upheld the constitutionality of this procedure.

93 I.R.C. $\$ \$ 9012(\mathrm{a}), 9042(\mathrm{a})$.

04 Id. $\$ \$ 9012(\mathrm{~d}), 9042(\mathrm{c})$. For the range of penalties that the FEC may impose, see notes $160-63$ infra \& accompanying text.

952 U.S.C. $\$ 437 \mathrm{c}(\mathrm{a})$ (Supp. III 1979).

96 Id. $\$ 437 \mathrm{c}(\mathrm{f})$.

$87 \$ 437 \mathrm{c}(\mathrm{b})(\mathrm{I})$.

$98 I d . \$ 437 \mathrm{~d}(\mathrm{a})$.

99 See id. $\$ \$ 437 \mathrm{~d}(\mathrm{a})(9), 437 \mathrm{~g}(\mathrm{c})-(\mathrm{d})$.

100 I.R.C. $\$ 9012$ (f) (originally enacted in Revenue Act of 1971, Pub. L. No. 92-178, $\$ 801,85$ Stat. 562).

101424 U.S. 1 (1976). 
mittees from making independent expenditures of more than $\$ 1,000$ to promote a candidate's campaign. Their most obvious argument was based on the "plain language" 102 of the provision. Section 9012(f)(1) provides, in pertinent part, that

it shall be unlawful for any political committee which is not an authorized committee with respect to the eligible candidates of a political party for President and Vice President in a presidential election knowingly and willfully to incur expenditures to further the election of such candidates, which would constitute qualified campaign expenses if incurred by an authorized committee of such candidates, in an aggregate amount exceeding $\$ 1,000 .^{103}$

As the district court held, then, the section prohibits "all expenditures over $\$ 1,000$ by political committees including "independent expenditures." "104

The plaintiffs also argued that the policies of the Act supported their interpretation of section 9012(f). They claimed that the provision promoted the federal election laws' primary purpose, indentified in Buckley as the limitation of

the actuality and appearance of corruption resulting from large individual financial contributions.... To the extent that large contributions are given to secure a political quid pro quo from current and potential office holders, the integrity of our system of representative democracy is undermined....

Of almost equal concern as the danger of actual quid pro quo arrangements is the impact of the appearance of corruption stemming from public awareness of the opportunities for abuse inherent in a regime of large individual financial contributions. ${ }^{105}$

This view of the Act's policies was echoed recently in Republican National Committee v. FEC, ${ }^{106}$ in which the court noted that one

102 Common Cause, slip op. at 4.

103 I.R.C. $\$ 9012(f)(1)$.

$10 \pm$ Common Cause, slip op. at 4 (emphasis in original).

105424 U.S. at $26,27$.

Regardless of the extent to which $\$ 9012(f)$ promotes the legislative purpose, the provision remains something of a mystery. The legislative history on the provision is sparse, highlighted only by a comment that the conference agreement eliminated the application of criminal penalties to "individuals" in addition to "political committees." H.R. Conf. ReP. No. 708, 92d Cong., 1st Sess. 58, reprinted in [1971] U.S. CoDE ConG. \& AD. NEws 2053, 2078. Common Cause was the first action brought under $\$ 9012(f)$ in its nine years of existence.

106487 F. Supp. 280 (S.D.N.Y. 1980), aff'd, 100 S. C. 1639 (1980). 
of the chief goals of the public financing scheme is the elimination of "'reliance on large private contributions' and on the implicit obligations to private contributors that may arise from such reliance." 107

In a defensive posture, Common Cause found it necessary to argue the constitutionality of section $9012(\mathrm{f})$. It contended that, unlike the provision struck down in Buckley, which had applied to all individuals, groups, committees, and associations, section 9012(f) was not unconstitutional: it was tailored narrowly in order to encompass only political committees, and it served a compelling governmental interest-the prevention of the corrupting "implicit obligations" created by large contributions. Common Cause argued that Congress intended section 9012(f) to apply only to "centrally managed organizations . . . that solicit money from strangers, aggregate it and decide how to spend it." These groups pose greater dangers of corruption, the plaintiff contended, than do "informal groups of persons." 108

\section{The District Court's Holding}

The three-judge district court ${ }^{109}$ unanimously rejected the plaintiffs' 110 claims under section 9012(f), holding that although the section does apply to the defendant committees, it violates the first amendment. The court's opinion, though inadequate in some respects, ${ }^{111}$ is essentially sound. Its significance lies in the way that it applies Buckley to give to independent political committees first amendment protection against narrowly drawn spending limitations.

\section{a. A Review of the Buckley Decision}

In reaching its holding, the district court began with a review of the first amendment analysis relied upon in Buckley. There, the Supreme Court had ruled that, because the FECA's contribution and expenditure limitations operate in the area of political ex-

107 Id. 284 (quoting S. REP. No. 689, supra note 11, reprinted in [1974] U.S. CODE CONG. \& AD. NEwS 5587, 5591-92).

108 Plaintiffs' Opening Brief on the Merits at 40, 41, Common Cause, No. $80-$ 1609 (D.D.C. Sept. 30, 1980), prob. juris. noted, 49 U.S.L.W. 3616 (U.S. Feb. 24, 1981) (No. 80-847).

109 The three-judge district court was convened pursuant to I.R.C. $\S 9011$ (b), mandating that suits to implement the Fund Act shall be heard by a three-judge panel "at the earliest practicable date," with appeals going directly to the Supreme Court. Id.

110 Common Cause and Americans for Change were consolidated for decision. III See text accompanying notes 134-49 infra. 
pression-the area of expression accorded the broadest first amendment protection-a strict scrutiny test must be used. ${ }^{112}$ The Court then proceeded to distinguish between contributions and expenditures, and concluded that the Act's expenditure ceilings "impose significantly more severe restrictions on protected freedoms of political expression and association than do its limitations on financial contributions." 113 The Court reasoned:

A restriction on the amount of money a person or group can spend on political communication during a campaign necessarily reduces the quantity of expression by restricting the number of issues discussed, the depth of their exploration, and the size of the audience reached. This is because virtually every means of communicating ideas in today's mass society requires the expenditure of money. ...

By contrast ... , a limitation upon the amount that any one person or group may contribute to a candidate or political committee entails only a marginal restriction upon the contributor's ability to engage in free communication. A contribution serves as a general expression of support for the candidate and his views, but does not communicate the underlying basis for the support. ${ }^{114}$

In effect, the Court was distinguishing between direct and indirect interests in speech, ${ }^{115}$ a distinction it relied on again when analyzing the Act's impingement of protected associational freedoms:

[T] he Act's contribution limitations permit associations and candidates to aggregate large sums of money to promote effective advocacy. By contrast, the Act's $\$ 1,000$ limitation on independent expenditures ... precludes most associations from effectively amplifying the voice of their adherents, the original basis for the recognition of First Amendment protection of the freedom of association." 116

On the basis of these principles, the Buckley Court upheld the Act's limitations on contributions ${ }^{117}$ because of the strong gov-

112424 U.S. at 16.

113 Id. 23.

114 Id. 19-21 (footnote omitted).

115 See Polsby, supra note 7.

118424 U.S. at 22.

117 Id. 29. 
ernmental interest in preventing the "actuality and appearance of corruption," 118 but at the same time it found the governmental interest not sufficiently threatened by independent expenditures to justify the Act's ceiling in that area. ${ }^{119}$ Significantly, this conclusion was based partly on the Court's observation that "the independent advocacy restricted by the provision does not presently appear to pose dangers of real or apparent corruption comparable to those identified with large campaign contributions." 120

Another clearly identified congressional purpose behind the expenditure limitations was the protection of the overall regulatory scheme. That is, the expenditure limitations, the Senate Rules and Administration Committee reported, ${ }^{121}$ were needed to prevent contributors who had given up to their contribution limits from circumventing such limits by disguising further contributions in the form of expenditures. The Supreme Court addressed this concern, but found it, too, lacking. It noted that because any expenditures coordinated with the candidate or his campaign would be treated as contributions under the Act, the contribution ceilings will "prevent attempts to circumvent the Act through prearranged or coordinated expenditures amounting to disguised contributions." 122 Although this does not entirely address the problem, in that a supporter could still aid a candidate by making uncoordinated expenditures, the Court did theorize that the absence of coordination between a candidate and a person making an expenditure in his behalf tends to undermine the value of the expenditure to the candidate and also "alleviates the danger that expenditures will be given as a quid pro quo for improper commitments from the candidate." 123

Finally, the Court considered the argument that a governmental interest "in equalizing the relative ability of individuals and groups to influence the outcome of elections" 124 justified the expenditure limitation. This argument expressed the idea that the regulatory scheme, by placing relatively low limits on both contributions and expenditures, served to minimize the disparity between large and small donors with respect to the potential effect

118 Id. 26.

119 Id. 51. For the text of the independent expenditure provision that was invalidated by Buckley, see note 3 supra.

120424 U.S. at 46 (emphasis added).

121 See note 11 supra.

122424 U.S. at 47. See text accompanying notes 92-94 supra.

123424 U.S. at 47 . See note 191 infra.

124424 U.S. at 48. 
that their spending could have on the election. The Buckley analysis, however, dismissed this consideration quickly, stating that "the concept that government may restrict the speech of some elements of our society in order to enhance the relative voice of others is wholly foreign to the First Amendment. . ." 125 According to this view, Congress cannot attempt to ensure equal spending on behalf of candidates if it involves infringing first amendment rights. ${ }^{126}$

\section{b. The District Court's Application of Buckley}

Given the Supreme Court's strong language in Buckley, the plaintiff, to maintain an action against an independent political committee under section $9012(\mathrm{f})$, would have to demonstrate that expenditures by this relatively new type of group ${ }^{127}$ create greater potential evils than do independent expenditures by individuals or by other, less formally structured, groups. To that end, the plaintiff in Common Cause proferred a definition of political committees that characterized them as centrally managed organizations that solicit funds by mail. ${ }^{128}$ Although that definition finds no support in the language or the legislative history of the statute, the court was willing to accept the position that the term "political committees" refers to formally organized collectives as opposed to "informal groups." 129 Oddly, however, the court gave no further consideration to the role of central management in the functioning of these committees. The court seemed content to rely upon an unrealistic image of the committees as "simply 'pooling agents' for many small voices wishing to make intelligible political statements." 130

The court rejected the argument that greater evils inhere in independent political committees than in individuals or informal independent groups: the committees could not be restricted simply because they are more effective in promoting their views. ${ }^{131}$ Most importantly, when addressing the specific evil that was focused on

125 Id. $48-49$.

126 See note 223 infra \& accompanying text.

127 See text accompanying notes 21-24 supra.

128 See text accompanying note 108 supra.

129 Common Cause, slip op. at 14. Without a limiting construction of "political committees," $\$ 9012(f)$ might suffer from unconstitutional vagueness. Specificity is required because "First Amendment freedoms need breathing space to survive." NAACP v. Button, 371 U.S. 415, 433 (1963).

130 Common Cause, slip op. at 13.

131 Id. 14. 
in Buckley, the court concluded that independent political committees do not engender corruption, and that therefore the governmental interest in eliminating corruption is insufficient to sustain the provision. The court stated that "[a]ny attempted exaction of a quid pro quo by a political committee would of course totally eliminate the constitutional protection reserved under Buckley for expenditures that are independent." 132 Apart from such conduct, however, the district court decided that independent expenditures by political committees do not pose any greater problems of corruption than do the other types of independent expenditures found constitutionally protected in Buckley. This conclusion was based in large measure on the court's idea, noted above, of how the committees function. Without considering the status of the committee leaders, the court wrote that "[i]t is difficult . . . to imagine how the thousands of 'small voices' associated together in a political committee could compromise a candidate for President." ${ }^{133}$

\section{Criticism of the Court's Holding}

The district court's opinion in Common Cause and Americans for Change may be criticized on at least two counts. First, the court failed to consider the governmental interest in preventing the "appearance of corruption," which was discussed in Buckley in conjunction with the interest in preventing corruption itself. Some evidence exists, in the form of newspaper editorial responses to "those 'independent' fat-cat spenders," 134 that the political committees do create an appearance of corruption. Even if this concern could be satisfactorily substantiated, however, it is uncertain what weight it should, standing by itself, be afforded.

Second, the court failed to provide a more probing examination of the political impact of large expenditures by centrallymanaged committees. This fault results from the court's failure to adequately distinguish between the thousands of contributors to a large committee and the organizers and managers of that committee. The court virtually equated the contributor's first amendment rights with the communications drafted by the executive committee of the group, because it perceived the organizers of a political com-

132 Id. 17.

133 Id.

134 See, e.g., N.Y. Times, Sept. 22, 1980, at A26, col. I (editorial entitled "The Fat Cats Revisited"); Wash. Post, Oct. 1, 1980, at A16, col. 1 (editorial entitled "The Sham of it All"). 
mittee as being merely "agents" 135 for contributors, "bound to reify the political thoughts of their member-contributors," 136 and "only mobiliz[ing] existing political sentiment looking for an outlet. ..."137 Contributors have effective power over the speech disseminated by political committees, the court postulated, because if "a committee disappoints its membership, contributions will dry up." 138

The court's analysis is based upon several unsupported and unsupportable assumptions. At the outset, it seems to posit some sort of ongoing interaction between the leaders and contributors of a political committee. The currency of this interaction is the flow of contributions, increasing and decreasing according to the satisfaction level of contributors. This paradigm may be appropriate when applied to mature, permanent, multicandidate committees that solicit funds from a core group of patrons and extend their operations beyond mass mailings. ${ }^{139}$ The model is inappropriate, however, when applied to many of the committees that sprung up during the 1980 Presidential election. ${ }^{140}$ Many of these existed solely for the purpose of backing one particular candidate in one particular campaign; they did not exist before the campaign and they disappeared after it was over. It is difficult, if not impossible, to conceive of contributors effectively controlling the operations of such organizations. Contributors are solicited at arms length through personally-addressed, yet standardized form letters. The money of a Delaware contributor may be used to buy radio time in Texas. Indeed, the committee may solicit funds nationally but spend them only in states in which the election is hotly contested or which have a large number of electoral votes. Nothing about this type of committee suggests that a contributor will have any idea how his money is being spent. Moreover, even assuming that a contributor could obtain that information, he would probably not be able to change the course of expenditures if he so desired. First, the influence of an individual contributor is limited by the

135 Common Cause, slip op. at 14.

136 Id. 16.

137 Id. 21.

138 Id. 14.

139 Such activities might include, for example, grassroots organizing similar to that of a political party. Such an organizing effort was attempted by Americans for Change. See campaign literature of Americans for Change (on file with the University of Pennsylvania Law Review). The result of this effort is unknown.

140 Note that permanent, multicandidate committees may undertake a "project" on behalf of a particular candidate that, to an average small contributor, is indistinguishable from a temporary, one-candidate committee. For a description of the major 1980 committees, see text accompanying notes 36-55 supra. 
FECA $\$ 5,000$ limit on individual contributions to a political committee.141 Most contributors probably do not give up to that limit, ${ }^{142}$ and the amount is small both relatively (compared to the hundreds of thousands of dollars spent by a major committee) and absolutely (in light of the cost of a single television commercial in a large media market). Second, if an individual does contribute up to his legal or personal limit, he loses any influence he may have once derived from his control over further contributions. Because there is nothing left to "dry up," he has lost his weapon to demonstrate displeasure with the conduct of the committee.

Perhaps the most serious consequence of the court's analysis for the federal election laws, therefore, is its failure to take into account the potentially significant amount of influence that committee managers might have on the election process. By reasoning that any potential for actual or apparent corruption by independent political committees was sufficiently disposed of by the limitation on individual contributions to the committees, ${ }^{143}$ the court completely ignored the ramifications of their hierarchical, centralized structures. Treating political committees as horizontal, albeit formalized, organizations is justified only if the managers of these committees are merely agents for their contributors. As has been seen, however, that approach is unrealistic; at best, it is a fiction.

The court's opinion would have been more accurate had it recognized the independent committees as organizations created by political entrepreneurs who, through means of technologicallyadvanced fundraising, collect small amounts of money from many people, aggregate those sums into huge funds, centralize control over the expenditure of these funds in small groups of managers, and concentrate their efforts on electing one or a few selected candidates. If this characterization of political committees is accepted, the case for finding a strong congressional interest that validates the regulation of these groups becomes more forceful, assuming that the final step, as mandated by Buckley, can be taken: a demonstration of the existence of real or apparent corruption stemming from their unfettered expenditures. In the context of corporate expenditures for a particular candidate, the Supreme Court has suggested that, if the current prohibition ${ }^{144}$ is challenged, such a showing could

1412 U.S.C. $\$ 441 a(a)(I)(A)$ (1976).

142 Unfortunately, this estimate will not be verifiable until the FEC releases its final report covering independent committees, and that will not take place until after this Comment has gone to press.

143 Common Cause, slip op. at 18-19.

144 See note 194 infra \& accompanying text. 
possibly be made. ${ }^{145}$ If that were the case with regard to independent committees, the first amendment interest in allowing uncontrolled expenditures could conceivably be overridden, and the limitations justified. ${ }^{146}$

In theory, at least, the basis for this demonstration already exists. It is widely agreed in the scholarly literature on campaign finance that one of the effects of large contributions in election campaigns is to provide the contributor with access to the candidate after he is elected. Even if the contributor does not "buy" a commitment on a specific issue, a sympathetic hearing from the elected official is generally assured. ${ }^{147}$ It seems reasonable to assume that an independent committee organizer who raises and spends hundreds of thousands of dollars on behalf of a candidate might get the same treatment as a large contributor. ${ }^{148}$ In the case of the pro-Reagan committees, this is a factual question presently without an answer. In the case of independent committees generally, as Fred Wertheimer of Common Cause has remarked, "there is no track record. . . . It hasn't been done this way before, so there is nothing to point to now and say "This is corrupting.' "148

\section{Challenges to the Independence of the Committees}

If the statutory limits on independent committees' expenditures are constitutionally invalid, the committees' expenditures can be constrained by law only if it is proved that they are not truly independent. Challengers to these committees must show that, as a factual matter, the challenged committees are "coordinated" with a candidate or candidates. Once this is done, the committees' expenditures will be limited because the Act treats coordinated expenditures as contributions, ${ }^{150}$ and under Buckley contribution limitations are permissible. ${ }^{151}$

146 First Nat'l Bank of Boston v. Bellotti, 435 U.S. 765, 788 n.26 (1978).

148 See Buckley, 424 U.S. at 26.

147 See, e.g., D. Dunn, Financing Presmenntal Campaygns 20-22 (1972) (citing D. Truman, The Governmental Process 264 (1951); A. Heard, The Costs OF DEMOCRACY 88-89 (1960).

148 This seems especially likely for those committees that are headed by Iongtime political professionals. See notes 54 \& 55 supra \& accompanying text. There are factors, however, that detract from the amount of influence that committee managers may be able to wield after an election, and these may be quite significant in some elections. See notes 191 \& 192 infra \& accompanying text.

149 Wall St. J., June 19, 1980, at 20, col. 5.

150 See text accompanying notes 92-94 supra.

151 See text accompanying notes 112-18 supra. 


\section{The FEC's Exclusive Jurisdiction}

Congress has provided the FEC with "exclusive jurisdiction with respect to the civil enforcement" of the FECA. ${ }^{152}$ As a result, a private party seeking enforcement of the Act must first file a complaint with the FEC. ${ }^{153}$ If the Commission determines that it has reason to believe a violation of the Act has been or is about to be committed, it must conduct an investigation of the alleged violation. ${ }^{154}$

When the FEC undertakes an investigation into allegedly coordinated committee expenditures, it applies several tests, of varying degrees of difficulty, to evaluate the merits of the charge. It considers an expenditure not independent when the expenditure is "made with the cooperation or with the prior consent of, or in consultation with, or at the request or suggestion of, a candidate or any agent or authorized committee of such candidate." 155 These circumstances have legal significance only if they occurred "prior to the publication, distribution, display, or broadcast of the communication." ${ }^{156}$ Where an expenditure has been made on behalf of a candidate by a current or former officer or employee of the candidate's committee, there is a presumption that it is not independent. ${ }^{157}$ Such a presumption also arises if the expenditure was based on information about the candidate's campaign that was provided by the candidate or his agents "with a view toward having an expenditure made." 158 Finally, any expenditure to disseminate or republish a broadcast or other written campaign materials prepared by a candidate or his agents is considered, for purposes of the independent committee's limitations, a contribution to the candidate, but is not considered an expenditure by the candidate unless it would otherwise qualify as a coordinated expenditure. ${ }^{159}$

In conjunction with the limitations on coordinated expenditures, the Act provides substantial penalties for violations. Although "conciliation agreements" are preferred, ${ }^{160}$ the Commission may institute an action in district court to impose civil penalties

1522 U.S.C. $\$ 437 \mathrm{c}(\mathrm{b})$ (1) (Supp. III 1979).

153 Carter-Mondale, slip op. at 8; Common Cause, slip op. at 26; In re Federal Election Campaign Act Litigation, 474 F. Supp. 1051, 1053 (D.D.C. 1979).

1542 U.S.C. $\$ 437 g(a)(2)$ (Supp. III 1979).

15511 C.F.R. $\$ 109.1$ (a) (1980).

156 Id. $\$ 109.1(\mathrm{~b})(4)(\mathrm{i})$.

157 Id. $\$ 109.1$ (b) (4) (i)(B).

$158 I d . \S I 09 . I(b)(4)(\mathrm{i})(\mathrm{A})$.

$159 \mathrm{Id}$. $\$ 109.1$ (d)(1).

160 See note 165 infra \& accompanying text. 
of up to the greater of $\$ 5,000$ or the amount of the contribution or expenditure involved. ${ }^{161}$ If the Commission finds that a knowing and willful violation has been committed, it may seek a penalty of the greater of two times the above amounts. ${ }^{162}$ Additionally, any person who knowingly and willfully commits a violation involving a sum of over $\$ 2,000$ may be subject to one year's imprisonment and a fine of the greater of $\$ 25,000$ or three times the amount involved in the violation. . $^{163}$

The Act requires that the FEG conduct its investigations "expeditiously." ${ }^{164}$ At the same time, however, it requires the Commission to encourage voluntary compliance by seeking "conciliation agreements" with alleged violators, ${ }^{165}$ a process that may not lead to the speediest enforcement of the Act. ${ }^{166}$ The Act contains a schedule according to which the FEC must act upon the complaints filed with it. Where the Commission determines that there is probable cause to believe that a violation has occurred or is about to occur, it must try, for at least thirty days, to resolve the matter through informal methods of conciliation. ${ }^{167}$ These attempts are supposed to continue for not more than ninety days. ${ }^{168}$

After waiting 120 days for the FEC to act, the party questioning the independence of a committee may seek judicial review of the agency's failure to act. ${ }^{169}$ Thus, "until an investigation is completed, and the FEG has issued an order, or the statutory time limit for action has expired, the FEG is allowed to conduct its investigation... without judicial interference." ${ }^{170}$ After that period, the courts of appeals have jurisdiction to review the FEC's action or inaction on the complaint. The standard of judicial review at this point is whether the agency has acted arbitrarily, capriciously, or contrary to law. ${ }^{171}$

1612 U.S.C. $\$ 437 \mathrm{~g}(\mathrm{a})(6)$ (A) (Supp. III 1979).

162 Id. $\$ 437 \mathrm{~g}(\mathrm{a})(6)(\mathrm{C})$.

$163 \mathrm{Id}$. $\$ 437 \mathrm{~g}(\mathrm{~d})(\mathrm{I})(\mathrm{A})$.

$164 I d . \$ 437 \mathrm{~d}(\mathrm{a})(9)$.

$165 I d . \$ 437 \mathrm{~g}(\mathrm{a})(4)(\mathrm{A})$.

166 See notes $172-85$ infra \& accompanying text.

1672 U.S.C. $\$ 437 \mathrm{~g}(\mathrm{a})(4)$ (A) (i) (Supp. III 1979).

$168 \mathrm{Id}$. The mandatory conciliation period is reduced to a minimum of 15 days if the Commission's probable cause determination occurs during the 45-day period immediately preceding an election. Id. $\$ 437 \mathrm{~g}(4)$ (A)(ii).

${ }^{169} \mathrm{Id}$. $\$ 437 \mathrm{~g}(\mathrm{a})(8)(\mathrm{A})$. The party must file his complaint in the United States District Court for the District of Columbia. Id. Note, however, that if the party is challenging an FEC certification or determination, as was the case in Carter-Mondale, judicial review takes place in the United States Court of Appeals for the District of Columbia. I.R.C. $\$ 9011(\mathrm{a})$.

170 Carter-Mondale, slip op. at 11.

171 Id. 9; Common Cause v. FEC, 489 F. Supp. 738, 742 (D.D.C. 1980). 


\section{The Slow Pace of Enforcement}

In practice, the operation of the scheme outlined above renders truly expeditious enforcement unlikely. By requiring an exhaustion of administrative remedies before court action can be instituted, ${ }^{172}$ the complainant is subjected to what some see as an overly slow pace of FEG enforcement. One study in late 1977 found the following:

Of more than 480 complaints submitted to the commission since 1975, all but 54 remained unresolved in November 1977 or had been settled during preliminary stages of investigation. ... Despite the statutory requirement that the commission act on all complaints within 90 days, a review of 100 complaints received by the agency between July and mid-October 1976 indicated that only 51 had been so handled-and 22 cases remained open one year later. ${ }^{173}$

The courts have not discouraged this slow pace. For example, in an earlier case, Common Cause v. FEC, ${ }^{174}$ the Commission took about three years to find probable cause, and well over ninety days to conclude conciliation agreements with the target political action committees. ${ }^{175}$ While the court was "disturbed" by the elapsed length of time, ${ }^{170}$ it approved the extension the FEC was requesting because by the time of its decision the FEC was anticipating that the remaining committees would quickly enter into conciliation agreements. $17 \tau$

The Carter-Mondale Committee had its complaint on file with the FEC since July 2, 1980; ${ }^{178}$ Common Cause has had its on file since September 26. ${ }^{179}$ Yet, despite the significance of these matters

172 See, e.g., Carter-Mondale, slip op. at 8; Common Cause, slip op. at 25, 26.

$173 \mathrm{H}$. ALEXANDER, supra note 21, at 139-40. Because these statistics fail to account for the number of cases closed after preliminary review, they may overstate the sluggishness of FEC enforcement. Whatever inaccuracy this may cause, it is probably minimal. In its Annual Report for 1979, the FEC reported that its enforcement caseload had been twice as large as in 1977, the most recent nonelection year. In addition, "in 1979, the majority of all cases proceeded beyond preliminary review and required investigation, reversing the trend of previous years." [1979] FED. Election CoMM. ANs. Rep. 22 (footnote omitted). The increasingly complex legal and factual issues found in these cases frequently require longer initial investigative periods. Id.

174489 F. Supp. 738 (D.D.C. 1980).

175 Id. $742-45$.

176 Id. 744.

177 Id.

178 Carter-Mondale, slip op. at 2.

179 Telephone interview with Ellen Block, attorney for Common Cause. 
for the 1980 campaign, they were not resolved by election day. Should the FEC now determine that the committees were coordinated with the candidate, the result would be insignificant. Although the candidate or his committee may have to repay to the Treasury the amount expended by the "independent" committees, ${ }^{180}$ or pay a fine, ${ }^{181}$ the outcome of the election has already been determined. At least for the victor of a presidential election, the cost of a violation may be meaningless. ${ }^{182}$

The operation of the statutory scheme thus appears somewhat ineffective, but the delays may be unavoidable. The time required to make factual investigations into "independence" simply might not be reducible to a more acceptable level, in part because the Commission is not always given the cooperation of the respondents to administrative complaints, who can purposefully delay investigative efforts. ${ }^{183}$ Ideally, the FEC could be required to give expedited attention to charges challenging a committee's true independence. ${ }^{184}$ In an election context, however, where any number of other types of violations might also merit speedy treatment, it is not clear that this would be appropriate. Finally, providing private access to the courts for purposes of seeking injunctive relief would not be feasible. As the district court stated in Common Cause $v$. Schmitt:

It would be incongruous and cumbersome for a threejudge court, ordered by Congress to expedite its consideration, to supervise extensive discovery and receive detailed factual evidence. ... [A]n expedited judgment on compliance is not appropriate to a non-expert three-judge court evaluating in the first instance circumstances surrounding an election controversy. ${ }^{185}$

18026 U.S.C. $\$ 9007(b)(1976)$.

${ }^{181} I d$. $\$ 9012(a)$. A fine will be imposed only if the violation was knowing and willful. Id.

182 Of course, no suggestion is made here that either a court or the FEC should be empowered to undo an election on these grounds.

183 See, e.g., Common Cause v. FEC, 489 F. Supp. at 744: the court found that the "American Medical Association and other respondents in the administrative proceeding dragged their feet at every conceivable opportunity, requiring for example, on numerous occasions judicial intervention and enforcement of Commission subpoenas, otherwise regular and proper."

$184 C f$. National Labor Relations Act, $\S 10(1), 29$ U.S.C. $\$ 160(1)$ (1976) (certain types of unfair labor practice complaints given priority over other types of cases).

185 Common Cause v. Schmitt, slip op. at 23-24. Cf. Leventhal, Courts and Political Thickets, 77 Colum. L. Rev. 345, 386-87 (1977) (congressional mandate that a court should expedite its considerations should not be construed "as requiring the court to rush to decision before it is ready"). 


\section{The Outlook for Future Elections}

\section{A. The Independent Committees}

Because the recent cases brought under the federal election laws have served to accentuate those laws' inadequacies, at least with regard to independent political committees, the result may be to encourage even further the proliferation of such organizations. When the Buckley $v$. Valeo ${ }^{186}$ decision was handed down in 1976, it was predicted in congressional hearings that the committees would become increasingly important. ${ }^{187}$ Similarly, Professor David Adamany made a well-founded prediction that "the $\$ 1,000$ individual limit [on contributions to candidates], while reducing the influence of big givers, probably increases the importance of wellconnected solicitors, of ideological money, and of mass mail specialists." 188 Campaign finance expert Professor Herbert Alexander reported in 1979 that "political fund-raising patterns are changing. To the extent that the wealthy donor is now limited, focus is shifting to fund-raisers who can organize and solicit interest groups." 183 Thus, the trend toward more potent independent committee activity, which began in the aftermath of the Buckley decision, may accelerate in the 1984 campaign in light of the 1980 experience with the enforcement of the relevant FECA provisions. It is likely that the 1984 campaign will see a spate of challenges to independent committees; however, it is also likely that, even if valid, these challenges will bear no fruit during the campaign. Unless Congress once again rewrites the election laws, its policy of limiting the role of private money in determining elections may be thwarted.

Beyond that prediction, however, little can be said about the effect that independent committees' expenditures have had or will have on the integrity of our political processes and election laws.

186424 U.S. 1 (1976).

187 At the hearings before the Subcommittee on Privileges and Elections of the Senate Rules and Administration Committee, George Agree, Director of the Committee for Democratic Process, commented on the invalidation of the independent expenditure limitations: "Every precedent in the history of campaign finance regulation supports the expectation that unchecked streams of money will flow again, albeit somewhat indirectly through the independent committees." Federal Election Campaign Act Amendments of 1976: Hearings before the Subcommittee on Privileges and Elections of the Senate Committee on Rules and Administration, 94th Cong., 2d Sess. 173, 175 (1976) (statement of George Agree), reprinted in FEDERAL. ELEcition Comarssion, supra note 15, at 179, 181. 1976).

188 Adamany, The Sources of Money: An Overview, 425 Annals 17, 30 (May

$189 \mathrm{H}$. Ar.eXander, supta note 21 , at 661 . 
Political analysts disagree on the question. ${ }^{190}$ There is some speculation that the efforts of some of these groups may have hindered more than helped the candidates they supported. ${ }^{191}$ Many conservative committee leaders are already claiming that they have been forgotten by the Reagan administration that they helped to elect. ${ }^{192}$ Concerns about disparities in spending also may diminish if, as suspected, those on the other end of the political spectrum from the majority of the existing committees form their own well-financed groups.

The issue of independent expenditures cannot be addressed in isolation from the other issues confronting the electoral process. The independent committees may be a vehicle for involving in the political process previously disenchanted and ignored voters. ${ }^{193}$ Stifling these groups may then achieve only undesirable "reform" at the cost of enhancing the influence of established corporate and labor groups.

\section{B. Corporate and Labor Committees}

Corporation and labor union political action committees (PACs) pose a problem similar to that created by the growth of

190 Compare Alexander, Election Reform: A Mixed Blessing?, CaMrpaigns \& Electrons 8 (Fall 1980) with Cohen, PAC Power: Why Common Cause Fears Its Impact, CampaIgNS \& ExEctions 13 (Summer 1980).

191 See, e.g., 'Independent' Groups Aim to Give Reagan Edge, N.Y. Times, June 23, 1980, at A21, col. 3; It's In, But How Powerful is the New Right?, Phila. Inquirer, Nov. 11, 1980, at AI, col. 3; Wall St. J., June 19, 1980, at I, col. 1 . A perceived problem with many of the independent efforts was that they ran a negative campaign, sharply attacking President Carter and his associates, while the official Reagan organization tried to run a generally positive campaign. The Supreme Court, in Buckley, pointed to the lack of "prearrangement and coordination" generally in predicting that independent expenditures would be of little value to the candidate, and would possibly be counterproductive. 424 U.S. at 47.

192 See, e.g., Phila. Inquirer, Nov. 15, 1980, at A1, col. 3. Cf. N.Y. Times, Jan. 18, 1981, at A18, col. 1 (comments of G.O.P. Chairman Richard Richards); N.Y. Times, Nov. 18, 1980, at BI0, col. 1 (comments of Vice President Bush). If so, this would appear to lend credence to another of the Supreme Court's contentions in Buckley: the absence of prearrangement of expenditures with a candidate minimizes the danger that the candidate will make improper commitments to committee organizers, 424 U.S. at 47.

193 Prior to the enactment of the FECA, most campaign financing came from a relatively small group of wealthy people who traditionally gave money for politics. See Adamany, supra note 188 . With the advent of individual contribution limitations, most candidates have had to reach greater numbers of people in order to raise the requisite funds. In great part, their efforts have been made possible by technological innovations such as complex office machinery and computer-generated direct mass mailings. Professional political consultants have played a key role in this revolution. See generally New Style in Electron Camopatens (R. Agranoff ed. 1976); H. Alexander, Financing Politics: Monex, Elections \& Poltrical ReForas 32-34 (1976). This technological and professional revolution is the basis of the independent political finance committee. See notes $46-49$ \& 53-55 supra \& accompanying text. 
independent political committees. As a general rule, it is unlawful for any national bank, corporation, or labor union to make either contributions or expenditures on behalf of any candidate in a federal election.194 This proscription, however, can be avoided by establishing a "separate segregated fund," 195 or PAC. Although the corporation or union cannot directly contribute money to or make expenditures for a candidate, it may finance the operation of a PAC that solicits contributions from its employees or members. ${ }^{196}$ The growth in the number of PACs, especially corporate PACs, has been extraordinary. In December 1974 there were only 89

194 See 2 U.S.C. $\$ 441$ b (1976 \& Supp. III 1979). There are certain exceptions to this rule. First, a corporation is permitted unlimited partisan communications to its stockholders and executive or administrative personnel and their families, and a labor union is permitted unlimited partisan communications to its members and their families. Second, unlimited non-partisan activities-such as registration and get-out-the-vote campaigns-by a corporation are permitted when aimed at its stockholders and executive or administrative personnel and their families, and by a labor union when aimed at its members and their families. Id. $\$ 441 \mathrm{~b}(\mathrm{a})(2)$. For labor unions, at least, these exceptions can be very significant: in some cases the numbers of voters involved "might add up to as much as half of a state's or a district's voting population." H. ALEXANDER, supra note 21, at 624 (footnote omitted).

1952 U.S.C. $\$ 441 b(b)(4)(c)(1976)$.

196 Id. See federal Election Commussion, Campatgn Gume for Polrtical Comomrtrees, reprinted in [1978] Fed. Elec. Campaign Fin. Guide (CCH) If 9063. The corporation or labor union may use its funds to cover, without limitation, the costs of office space, phones, salaries, utilities, supplies, and other expenses incurred in the operation of and fundraising for a PAC. 11 C.F.R. $\$ 114.1(\mathrm{~b})$ (1980). PACs may contribute to candidates in the same manner as other political committees, and are subject to the same contribution limitations as are political committees generally. Id. $\$ 114.5(\mathrm{f})$.

Corporations, labor unions, and their PACs are subject to special solicitation restrictions. Generally, a corporation or its PAC is permitted to solicit contributions only from its stockholders, executive or administrative personnel, and their families, while a labor union or its PAC may solicit contributions only from its members and their families. Id. $\$ 114.5(\mathrm{~g})(1)$ \& (2). Twice a year, however, a corporation may make written solicitations to the remainder of its employees for contributions to its PAC, and twice a year a labor union may make such solicitations to all the non-union member employees and stockholders of the corporations in which it represents members working for the association. Id. $\$ 114.6$ (a) \& (b). In no case may a corporation or labor union PAC secure funds by physical force, job discrimination, financial reprisals, or the threat thereof, or by dues or fees required as a condition of employment or membership. Id. $\$ 114.5(\mathrm{a})$.

For a discussion of the history of congressional regulation of corporate and union campaign contributions and expenditures, see Mager, Past and Present Attempts by Congress And the Courts to Regulate Corporate and Union Campaign Contributions and Expenditures in the Election of Federal Officials, 1976 S. IL.. U. L.J. 338 (1976), reprinted in Practusing Law Instruute, The Corporamon in Pourncs 1978, at 675 (1978). The constitutionality of these restrictions has been seriously and widely questioned as a result of Buckley, 424 U.S. 1 (1976), and First Nat. Bank of Boston v. Bellotti, 435 U.S. 765 (1978). See Birmbaum, The Constitutionality of the Federal Corrupt Practices Act After First National Bank of Boston v. Bellotti, 28 Ax. U. L. Rev. 149 (1979); Bolton, Constitutional Limitations on Restricting Corporate and Union Political Speech, 22 ARrz. L. REv. 373 (1980); Note, Corporate Political Action Committees: Effect of the Federal Election Campaign Act Amendments of 1976, 26 CATr. U. L. REv. 756 (1977). 
corporate PACs in existence; by October 1977 there were 508,197 and by December 1979 there were 949.198 By contrast, the growth of labor union PACs appears to have stabilized. In October 1977 there were 222 of them; in December 1979 there were 240.199 Overall, the total number of active registered PACs, as of December 1979 , was $2000 .^{200}$

Moreover, the influence of PACs seems to have increased in relative as well as absolute terms. Professor Alexander has noted that the limits placed on individual contributions "led to a relative increase in the importance of interest group donations. PACs sponsored by special interest groups have become more important, and the interest group component of campaign finance has increased while proportionally the individual component has decreased." 201

The chief distinction between corporate and union PACs on the one hand, and independent political committees on the other, is that PACs are limited as to the types of people that they may solicit for funds. ${ }^{202}$ As with political committees in general, there are no restrictions on the amount of money a PAC may spend in communications directed at the general public. ${ }^{203}$ Under the FECA, then, PACs potentially have as great an impact on elections and on the integrity of the federal election law scheme as do independent political committees. As a practical matter, PACs collectively have an advantage, because they have easily identifiable groups from which to solicit, and the money to cover the various expenses of a $P A C$ is readily available from its corporation or union. A given independent committee, however, if organized with sufficient resources to allow it to take advantage of the current techniques in political fundraising, may be able to collect funds on a scale far exceeding that of most PACs.

This Comment's proposal, which follows in the next section, would probably have less of an effect on corporate and union PACs

197 See Boggs, PACs: Business' Political Renaissance, Truax, Jan. 1978, at 5, 6.

198 Baran, Recent Developments in Federal Election Laws, in PRACTISng LAw Institute, The Corporation In Porrtics 1980, at 11.

199 Boggs, supra note 197, at 6.

200 Baran, supra note 198, at 11 .

201 H. Arexander, supra note 21, at 555. See also Sorauf, Political Parties and Political Action Committees, 22 Anz. L. REv. 445, 454-59 (1980).

202 See note 196 supra.

203 See id. See also Maloney, From Marketplace to Ballot Box: The Corporate Assertion of Political Power, 12 CoNN. L. REv. 14, 46 (1977). 
than it would on independent committees. The proposal is designed to siphon funds away from committees formed to aid specific presidential candidates, and to direct those funds back to the candidates themselves. Unlike an independent committee, however, a PAC is not created in order to promote certain candidates, but rather to promote primarily the interests of the corporation, bank, or union from which it is formed. ${ }^{204}$ As a result, a contribution to a corporate or union PAC may be at least partly motivated by a desire to promote the corporation's or union's interests, not the candidate's interests. Such contributions are less likely to be affected by an opportunity to contribute to presidential candidates directly during the general election. Any proposal that would tend to decrease the impact of independent political committees could therefore have the effect of increasing the relative impact of corporate and union PACs. To keep the influences in balance, then, some additional constraints should perhaps be placed on PACs if Congress places new restrictions on the independent committees. Although a full consideration of this question is well beyond the scope of this Comment, some suggestions are in order. First, PACs should be limited in the aggregate amount of money they may contribute to federal candidates in a calendar year. This suggestion is also made below with respect to independent multicandidate committees. ${ }^{205}$ Second, a limitation should be placed on the amount that a corporation or union can contribute to the expenses of the PAC or PACs that it establishes. This would diminish the advantage that these PACs already have relative to other political committees because of their ability to draw upon general corporate or union funds to pay for their expenses.

204 See generally $\mathrm{H}$. ALEXANDER, supra note 21, at 561. The different purpose of the PACs, as opposed to the independent committees, is exhibited in the way that the PACs spend their money. In the 1976 election, corporate PACs contributed to incumbent congressmen over their challengers by a ratio of $4: 1$. Id. 545 . Because incumbents have historically stood a greater chance of winning, this at least suggests that PACs are more interested in backing winners than in backing candidates with specific ideologies. In some cases, PACs give to opposing candidates in the same race, something that would be quite unexpected if done by an independent committee. Professor Alexander cites one case study in which a Southern Bell Telephone PAC gave money to each of the two Democratic and two Republican contenders in the 1972 North Carolina gubernatorial race. Id. 576.

205 See text following note 208 infra.

A similar proposal was made in the Congress with respect to contribution limits for House of Representative races. See the Campaign Contribution Reform Act of 1979 (popularly known as the "Obey-Railsback bill"), H.R. 4970, 96th Cong., 1st Sess., 125 Conc. REc. 8111, 9261 (1979). It was passed in the House on October 17, 1979, but was defeated in the Senate. For a discussion of it, see Alexander, The Obey-Railsback Bill: Its Genesis and Early History, 22 ARZz. I. . REv. 653 (1980). 


\section{A Legislative Proposal}

When pressure builds in one area of a system, in some cases it may be best alleviated not by treating it directly but by allowing an outlet for the pressure elsewhere in the system. This principle constitutes the basis upon which this Comment's proposal is built. Faced with constitutional barriers to restrictions on independent expenditures on one side, and statutory and systemic barriers to the expeditious, effective enforcement of coordinated expenditure limitations on another side, it may be difficult to impose a much greater degree of direct control on "independent" committees than that which already exists. Therefore, this Comment proposes a partial solution, intended to reduce the importance of some of the factors that have led to the increasing impact of these independent activities.

\section{Contribution and Expenditure Limitations}

The essence of this Comment's proposal is that Congress should allow contributions to be made directly to the candidate or his authorized committees during the general election as well as during the primaries. To implement this idea, several legislative changes would have to be made. ${ }^{208}$ First, the expenditure limitations on presidential candidates who accept public funding in the general election should be raised significantly, and the limitation on the amount that the candidate's political party can spend on his campaign should be repealed, except as subject to the new overall limitation. Temporarily, public funding levels should remain the same, but Congress should reevaluate the $\$ 20,000,000$ level ${ }^{207}$ of

206 For description and citation of the existing legislative provisions that are addressed below, see notes 66-94 supra \& accompanying text.

207 See note 86 supra \& accompanying text. The derivation of the $\$ 20$ million figure is not made entirely clear by the legislative history. The original Senate bill proposing amendments to the FECA in 1974 provided for public funding in presidential general elections of an amount equalling 15 cents multiplied by the voting age population. According to the Senate Report accompanying the bill, the figure in 1974 would have been $\$ 21,250,000$. S. REP. No. 689 , supra note 11 , at 26 , reprinted in [1974] U.S. CODE CONG. \& AD. NEws 5587, 5612. The House version, which was ultimately adopted in conference, provided instead for a flat $\$ 20$ million, plus an adjustment for inflation. The House Report states simply that the House amendment "eliminates the formula under which candidates of a major party would receive 15 cents multiplied by" the voting age population. H.R. ReP. No. 1239, 93d Cong., 2d Sess. 33 (1974), reprinted in Federal Erection Commission, Legislative History of Federal Election CaAppatgN Act AMENDMENTS of 1974, at 631,667 (1974). It seems reasonable to assume that Congress simply preferred the more rounded figure; regardless, however, the source of the original 15 cents figure remains uncertain. 
public funding in an attempt to determine the threshold amount of funding necessary to run a national campaign. ${ }^{208}$ Second, candidates who opt for public funding should be allowed to accept private funding as well, so long as they do not exceed the new expenditure limitation. Third, the contribution limitations should be adjusted by raising the limit on individual contributions to a candidate in any calendar year from the current $\$ 1,000$ to $\$ 5,000$, thereby equalizing the amounts a person can contribute to a candidate and to unauthorized political committees. Fourth, limits should be placed on the aggregate amounts that independent committees may contribute to all of their supported candidates in any given calendar year.

\section{2. "Floors, Not Geilings"}

The idea expressed above, that the government should provide grants to presidential candidates that supplement private money, is not a new one. Political scientists expert in the field of campaign financing have long advocated, in varying formulations, that "floors, not ceilings," should be enacted. ${ }^{209}$ As Professor Alexander has explained, "[f]loors mean the provision of government funds to ensure minimum access of the candidate to the electorate. Beyond that level, candidates can spend as much private money as they can raise." 210 This concept is accepted in a number of western democracies. ${ }^{211}$ The proposal advanced here incorporates a combination of public and private funding, but because it would retain an upper

208 Such a task is difficult, but not necessarily impossible. Political consultants are able to estimate a threshold for a statewide campaign in a state as Iarge as Pennsylvania. Telephone interview with Thomas Sweitzer of The Campaign Group, a Philadelphia political consulting firm (Jan. 6, 1981). Also, researchers are beginning to identify and measure the ability of media consumers to absorb and utilize information received through advertising and news programs. See, e.g., Patterson \& McClure, Television and the Less Interested Voter: The Costs of an Informed Electorate, 425 AnNals 88 (May 1976); Simon \& Arndt, The Shape of the Advertising Response Function, $26 \mathrm{~J}$. ADv. Res. 11 (1980). At a minimum, Congress should reassess the $\$ 20$ million figure, and in doing so should focus on the rising costs of campaigning rather than on the general rise of the Consumer Price Index. See note 86 supra \& accompanying text. This modification has been suggested elsewhere. See H. Alexander, Background Paper 14-15 (prepared for the Presidential Finance Officers' Conference, sponsored by the Citizen's Research Foundation, Washington, D.C., Dec. 5, 1980) (on file with the University of Pennsylvania Law Review).

209 See, e.g., D. Adamany \& G. Agree, Poltitcal Money 60-62 (1975); H. Auexander, Monex in Polrmics 93-95 (1972); D. Dunn, Financing Presidentiat Campatgas 150-52, 155 (1972).

210 Federal Election Campaign Act Amendments of 1976: Hearings, supra note 187, at 178, 181 (1976) (statement of Herbert Alexander), reprinted in FEDERAL. Election Comarssion, supra note 15, at 184, 187.

211 Id. Several countries provide funding to political parties instead of individual candidates. 
limit on candidates' expenditures it could be more accurately described as employing both floors and ceilings.

Partly as a result of the uproar over Watergate, Congress debated the adoption of partial subsidization plans when it considered amending the FECA in 1974.212 Senator Adlai Stevenson proposed an amendment to the Senate bill to amend the FECA that would have established a system of partial public financing, ${ }^{213}$ under which a presidential candidate would receive an entitlement of forty percent of his expenditures in the general election, plus matching funds for those contributions not exceeding $\$ 250 .{ }^{214}$ In its context as a proposed amendment to a bill providing for full public financing combined with limitations on both individual contributions and expenditures, the Stevenson proposal was widely regarded as a compromise measure designed to make the elections bill more passable. ${ }^{215}$ The amendment was rejected, but as events turned out, it was not necessary for the passage of the bill.

Two years later, Buckley $v$. Valeo struck down the limitation on independent expenditures. ${ }^{216}$ Although there was some anticipation of the effect that this would have on campaign financing, Congress gave no consideration to a partial funding system in its rush to accommodate the election laws to the Buckley decision. ${ }^{217}$

\section{Promotion of the Policies of the Act}

Adoption of this Comment's proposal would serve to promote several policies underlying the Act. First, by providing for the direct participation of individuals in the funding of the major presidential candidates' general election campaigns, it would help serve the "[f]ull enjoyment of the First Amendment rights of individuals and groups." 218 Second, by funnelling more funds

212 See the discussion of the Hart plan and the Stevenson-Mathias plan in 31 Conc. Q. 1877, 1885 (1973), reprinted in U.S. Senate Sex.ect Comm. on Presidential Campaign Activities, Elegtion Reform: Basic References 201 (1973).

213120 Cong. Rec. 10340 (1974), reprinted in Federal Election Commission, supra note 207 , at 438 . at 439 .

214 Id. 10341, reptinted in Fenerat. Election Commsston, supta note 207,

215120 Conc. Rec. 10343 (1974) (remarks of Sen. Humphrey), reprinted in Femeral Election Commission, supta note 207, at 440.

216 For a discussion of the Buckley opinion, see text accompanying notes 112-23 supra.

217 See text accompanying notes $13 \& 14$ supra.

218 H.R. Rep. No. 917, supra note 15, at 5, reprinted in FeDERAI Election Cosomassion, supra note 15 , at $797,805$. 
through the candidate's party organization, it would "encourage a specific type of contribution to such candidates in order to strengthen the party system." ${ }^{219}$ Third, by retaining an upper limit on a candidate's spending, it could help keep a continuing check on "spiraling campaign costs" 220 while freeing candidates from the current limits that are unrealistically low. ${ }^{221}$ Fourth, by drawing funds away from independent committees, thereby decreasing the relative impact of independent expenditures in election campaigning, the proposal could serve to prevent "an infinite proliferation of political committees which [are] ostensibly separate entities but which [are] in fact a means for advancing a candidate's campaign." 222

Fifth, the proposal would perhaps decrease the potentially great disparity in expenditures that can result in a given election from the existence of large independent expenditures for a particular candidate in conjunction with the ceiling on authorized expenditures by all candidates. It would thus promote the legislative objective of minimizing disparity in spending between the

Proposals that encompass a matching grant system, such as for contributions of up to $\$ 250$, could actually yield greater citizen participation by encouraging parties to seek support from numerous smaller contributors. See, e.g., Senator Stevenson's proposed amendment to the FECA Amendments of 1974, 120 CoNG. REc. 10341 (1974), reprinted in FeDERAL Election Commassion, supra note 207, at 438; H. Alexander, supra note 209, at 297; Agree, Public Financing, 425 Annals 134, 137 (May 1976). A matching system has been criticized, however, on the ground that it may tend to magnify the amount by which one candidate outspends another. In any case, a matching system would not be a necessary component of a plan to. provide an outlet for contributions directly to the candidate during the general election.

219 H.R. Rep. No. 917, supra note 15, at 6, reprinted in Federal Election Commission, supta note 15, at 797, 806.

220 H.R. REP. No. 1239, supra note 207, at 6, reprinted in FEDERAL ElectroN Comanssion, supra note 207, at 631,640 .

221 A number of campaign finance commentators have suggested that the current spending levels may be too low. See H. Arexander, Polmtical Frnancing 39 (1972); D. Dunn, Financing Presmential Campatgns 150 (1972); G. Thayen, Who Shakes The Money Tree? 274 (1973).

222 H.R. ReP. No. 917, supta note 15, at 5, reprinted in Federax Eucction Commrssron, supra note 15 , at 797,805 . It is assumed here that, first, the total contributions during a campaign are to some extent finite, and, second, many contributors would rather give directly to a candidate than aid him indirectly through an independent political committee. Of course, contributors could still give to both, but even if only some did not, the relative impact of the independent groups would decline. The type of empirical inquiry necessary to test the validity of the stated assumptions is beyond the scope of this Comment. A suggestion, at least, that the second assumption is valid can be found in the fundraising appeals of the independent committees. See text accompanying note 47 supra. The first assumption is lent support by research suggesting that, even though modern fundraising techniques may be able to exploit new sources of funds, the funding pool is not bottomless. See Adamany, supra note 188, at 19. 
candidates. $^{223}$ Spending disparities would continue to exist under the proposal, both because of independent expenditures and because candidates would raise different amounts of private funds to spend as they see fit. Disparities in spending would be minimized, however, to the extent that a candidate who does not have independent support could himself take the initiative in reducing the differential caused by the independent committees.

Most importantly, the proposal could help to reduce the possibilities for corruption, or the appearance of corruption, in federal campaigns. The greatest source of potential corruption in the independent committees is not the contributors to the committees, for which the contribution limitations remain applicable, but rather the committee managers who may be able to aggregate and spend millions of dollars on behalf of a candidate. To the extent that contributions would be given directly to the candidate, the accumulation of large sums of money controlled by independent committee managers would not occur to the same degree. It would thus seem to be less likely that "implicit obligations" would arise in connection with the independent expenditures. For the same reasons, an appearance of "subversion" of the election laws by these committees would be less likely.

In addition to furthering several important policies behind the FECA, adoption of this Comment's proposal could spawn other benefits. Perhaps the most likely is that, while overall spending on a presidential campaign would increase, a greater percentage of expenditures would be by authorized committees. The candidates would thereby gain greater control over their own campaigns, because they would control more of the funds expended on their behalf. They would also probably engage in more fundraising during the general election campaign than they presently do.

The effect that adoption of the proposed changes would have on the survival of the independent committees is hard to predict. It would neither eliminate them nor even inhibit them directly. The proposal merely reduces the need for them. Ideological committees may withstand these changes more easily than candidate-

223 The House Committee on House Administration made the following statement in its report on FECA 1974:

While independent expenditures may occur quite apart from the official campaign effort, they can and often do have a substantial impact on the outcome. Absent a limitation on this activity, well-heeled groups and individuals could spend substantial sums and thus severely compromise the limitations on spending by the supported candidate himself.

H.R. Rep. No. 1239, supta note 207, at 6, reprinted in Federal Exection ComMTSSION, supra note 207, at 631,640 . 
specific committees. The potential benefit flowing from adoption of the proposal is that as the need for surrogate campaign committees declines, it is more likely that remaining independent com. mittees would be truly independent.

Finally, under the proposal, enforcement would not be any more difficult than it already is, and, as George Agree explains, might actually be easier:

$[\mathrm{P}]$ artial public funding makes it possible to require that subsidies be segregated from other funds and used only for easily verifiable kinds of expenses, such as metered postage, printing bills, broadcasting time, billboards, and telephone charges. Salaries, personal expenses, petty cash, and other difficult-to-trace disbursements could be excluded from payment with government funds. In a system combining the use of both government and private money, it even would be possible not to give candidates the subsidy funds at all. The candidates could be required to submit certified bills for approved expenses which the government would then pay directly, as is done in Puerto Rico. ${ }^{224}$

\section{Conclusion}

Ultimately, Congress may find it permissible and beneficial to reenact a limitation on the expenditures of independent political committees. For now, however, such a limitation cannot pass constitutional muster, because there is insufficient evidence available that demonstrates the existence of problems of real and apparent corruption created by independent committees. Rather than wait until these problems have a chance to develop in the presidential election context, however, Congress should attempt to circumvent them by raising the overall expenditure limitation on presidential candidates and by permitting contributions to be made to them directly during the general election. The desired effect of this proposal would be to divert contributions toward the candidate that might otherwise have flowed to the independent committees.

224 Agree, Public Financing after the Supreme Court Decision, 425 AnNars 134, 140 (May 1976). 